\title{
Effect of Soil Temperature in the Emergence of Maize Seeds
}

\author{
Heloisa O. dos Santos ${ }^{1}$, Renato C. C. Vasconcellos ${ }^{1}$, Beatriz de Pauli ${ }^{2}$, Raquel M. O. Pires ${ }^{1}$, Elise M. Pereira ${ }^{1}$, \\ Giovani V. Tirelli ${ }^{1} \&$ Édila V. R. V. Pinho ${ }^{1}$ \\ ${ }^{1}$ Department of Agriculture, Lavras Federal University, Lavras, Brazil \\ ${ }^{2}$ Bayer Crop Science, Palmas, Brazil \\ Correspondence: Renato C. C. Vasconcellos, Department of Agriculture, Lavras Federal University, Lavras, MG., \\ 37200-000, Brazil. Tel: 55-31-97361-1864. E-mail: renatoccv@hotmail.com
}

Received: September 30, 2018

Accepted: November 2, 2018

Online Published: December 15, 2018

doi:10.5539/jas.v11n1p479

URL: https://doi.org/10.5539/jas.v11n1p479

\begin{abstract}
Temperature is one of the most important factors in the germination process, which influences the absorption of nutrients required for growth and development of the plant, germination uniformity, and seed vigor maintenance. Low temperatures can result in deformation of the leaves and the apex of the plant, and high temperatures hamper the development of them. The objective of this work was to evaluate the ideal temperature values for germination in each genetic material used, highlighting the most suitable for each condition. The experiment was conducted at the Central Seed Laboratory at the Department of Agriculture of the Lavras Federal University, where germination percentage, first germination count, seedling emergence and emergence speed were evaluated. The experimental design was completely randomized, with a factorial scheme of $4 \times 5$, in which it was analyzed four lines (L30, L64, L63, and L91) at five different germination temperatures $\left(15,20,25,30\right.$ and $\left.35^{\circ} \mathrm{C}\right)$. An analysis of variance was done and for the comparison between means, the Scott Knott test was used, at a 5\% probability. It can be observed that the lines L63 and L91 were more susceptible to low germination temperatures and lines L30 and L64 do not tolerate high temperatures. Also, the evaluation of temperature-controlled substrate germination proved to be a promising technique to identify tolerant and susceptible lines for germination in both high and low temperatures.
\end{abstract}

Keywords: Zea mays, vigor, abiotic stress

\section{Introduction}

Seeds are one of the main inputs of agriculture, being a determining factor for the success or failure of the crop implantation (Costa \& Campos, 1997). Its quality is what determines the uniformity, speed, and percentage of emergence in the field, reflecting on the final yield (Durães et al., 1993).

Maize is influenced by a set of edaphoclimatic factors, especially photoperiod, humidity, and temperature. (Fancelli \& Dourado Neto, 2000). Considered one of the most important factors in seed germination, temperature influences the absorption of water and nutrients necessary for the growth and development of seedlings, as well as the speed in which chemical processes occur (Carvalho \& Nakeagawa, 2000; Nerson, 2007).

When the seed expresses its maximum germination potential in the shortest time at a certain temperature, it is considered the optimum temperature, if the humidity is adequate and other stresses are minimal (Lopes et al., 2005). Studies show that this classification occurs for values around $25-30{ }^{\circ} \mathrm{C}$ in maize, and where the emergence occurs between four to seven days. Temperatures below and above the optimum value slow the germination process, causing the seeds to become less vigorous, and consequently suffer greater stress from the environment. The probability of being attacked by soil microorganisms under stress conditions increases, leading to a reduction in emergence and in the final stand of the crop (Silva Neta et al., 2015).

Temperature is one of the most important factors in the germination process, with influence on the absorption of nutrients required for growth and development, germination uniformity, and seed vigor maintenance. The selection and development of cultivars tolerant to periods of high or low temperature, as well as the development of technologies that help plants tolerate prolonged periods of drought will be essential in the maintenance of maize production. Therefore, the present work aimed to evaluate the ideal temperature values for germination, highlighting the most suitable genotypes for each condition. 


\section{Material and Methods}

\subsection{Location and Genotypes}

The research was conducted at the Central Seed Laboratory at the Department of Agriculture of the Lavras Federal University (UFLA), in Lavras, MG, Brazil.

Maize lines (L30, L64, L63, and L91) from Geneseeds Recursos Genéticos Ltda breeding program were used.

\subsection{Water Content}

The water content of the seeds was determined by the incubator method at $105^{\circ} \mathrm{C}$ for 24 hours (MAPA, 2009), using two replicates of 50 seeds of each treatment. After this period the seeds were taken to desiccators until the samples were cooled and the dry weight of the samples was carried out. The results were expressed as a percentage.

\subsection{Germination Test}

The germination test was conducted, with four replicates of 50 seeds, with sowing in Germitest-type paper moistened with distilled water in the proportion of $2.5 \mathrm{ml} \mathrm{g}^{-1}$ of paper. The seeds were incubated in B.O.D. chamber, set at temperatures of $15,20,25,30$ and $35^{\circ} \mathrm{C}$ and the normal seedlings evaluations were performed on two counts. The first on the fourth day and the last on the seventh day after sowing. The results were expressed as mean percentage of normal seedlings of the four replicates. It was considered normal seedling the ones that had all the essential structures well developed and proportional.

\subsection{Seedlings Emergence at Different Temperatures}

The emergence test was conducted with eight replicates of 20 seeds. The sowing was done in stainless steel containers, of $1200 \mathrm{~cm}^{3}$ containing a mixture of sand and soil (2:1), with field capacity of $60 \%$. Field capacity is calculated as the amount of water retained in the substrate, and $100 \%$ is the maximum of which the substrate can retain. Afterward, the containers were placed in a water bath to heat the pots and installed in a greenhouse with an average temperature of $25^{\circ} \mathrm{C}$. The temperatures used in the water baths were $15,20,25,30$ and $35 \pm 0.3{ }^{\circ} \mathrm{C}$.

In the water baths, thermometers were placed immersed in the substrate contained in the stainless steel containers to record its internal temperature. Soil temperature monitoring was done twice a day to ensure the right temperature, the first being in the early morning and the second in the late afternoon.

Daily evaluations were carried out from the beginning of the emergence, counting the number of seedlings emerged, until the stabilization of the stand. The percentage of normal seedlings was evaluated at 14 days.

\subsection{Emergence Speed}

The emergence speed was performed along with the emergence test, recording the number of seedlings emerged daily until the complete stabilization of the stand. The rate of emergence speed was determined according to the expression of Edmond and Drapala (1958):

$$
\mathrm{ES}=\frac{\left(\mathrm{N}_{1} \mathrm{E}_{1}\right)+\left(\mathrm{N}_{2} \mathrm{E}_{2}\right)+\ldots+\left(\mathrm{N}_{\mathrm{n}} \mathrm{E}_{\mathrm{n}}\right)}{\mathrm{E}_{1}+\mathrm{E}_{2}+\ldots+\mathrm{E}_{\mathrm{n}}}
$$

Where,

$\mathrm{ES}=$ emergence speed (in days); $\mathrm{E}_{1}, \mathrm{E}_{2}, \mathrm{E}_{\mathrm{n}}=$ number of normal plants emerged in the first, second and last count; $\mathrm{N}_{1}, \mathrm{~N}_{2}, \mathrm{~N}_{\mathrm{n}}=$ number of days after sowing of the first, second and last count.

\subsection{Statistical Procedures}

The experimental design was a completely randomized factorial scheme $(4 \times 5)$, analyzing four lines (L30, L64, $\mathrm{L} 63$, and L91) at different germination temperatures $\left(15,20,25,30\right.$ and $\left.35^{\circ} \mathrm{C}\right)$. The data were interpreted statistically by the analysis of variance for all the tests using the statistical program Sisvar ${ }^{\circledR}$ (Ferreira, 2014). For the comparison between means, the Scott-Knott Test was used, at a 5\% probability.

\section{Results and Discussion}

Based on the analysis of variance it was possible to observe significant differences between the lines and between the temperatures, as well as for the interaction of the factors evaluated $(p<0.05)$.

The mean water content of the seeds at the time of the tests was 12.8 with a maximum variation of $1 \%$. It is important to evaluate the water content between the tested materials with the lowest possible variation because high values of water content accelerate the deterioration process and the formation of products that lead to seed damages. 


\subsection{Normal Seedlings}

Lines L63 and L91 obtained lower normal seedlings percentages at temperatures of 15 and $20{ }^{\circ} \mathrm{C}$ in relation to the lines L30 and L64, respectively. However, in the temperature of $30^{\circ} \mathrm{C}$, lines L63 and L91 had higher normal seedlings percentages, which shows that these lines are more sensitive only to low temperature. The L91 tolerated high germination temperature at $35{ }^{\circ} \mathrm{C}$, followed by the L63, L30, and L64. All lines obtained good performance at $25^{\circ} \mathrm{C}$ (Table 1).

Table 1. Percentage of normal seedlings in the first germination test count of four maize lines at five germination temperatures

\begin{tabular}{lllll}
\hline \multirow{2}{*}{ Temperature $\left({ }^{\circ} \mathbf{C}\right)$} & \multicolumn{4}{c}{ Line } \\
\cline { 2 - 5 } & L30 & L64 & L63 & L91 \\
\hline 15 & $65 \mathrm{aC}$ & $61 \mathrm{aC}$ & $21 \mathrm{bC}$ & $20 \mathrm{bC}$ \\
20 & $66 \mathrm{aC}$ & $63 \mathrm{aC}$ & $32 \mathrm{bC}$ & $39 \mathrm{bB}$ \\
25 & $90 \mathrm{aA}$ & $92 \mathrm{aA}$ & $89 \mathrm{aA}$ & $95 \mathrm{aA}$ \\
30 & $73 \mathrm{cB}$ & $87 \mathrm{bB}$ & $94 \mathrm{aA}$ & $99 \mathrm{aA}$ \\
35 & $22 \mathrm{cD}$ & $16 \mathrm{cD}$ & $77 \mathrm{bB}$ & $91 \mathrm{aA}$ \\
\hline $\mathrm{CV}$ & 13.25 & & & \\
\hline
\end{tabular}

Note. Means followed by the same lowercase letter in the row, and upper case in the column, do not differ at $5 \%$ probability by the Scott Knott test.

Analyzing the temperatures within each line it was observed that lines L30 and L64 followed the same pattern for normal seedlings, where temperatures above $30^{\circ} \mathrm{C}$ compromised the seedling formation. Whereas the lines L63 and L91 obtained an increase of normal seedlings with the temperature elevation.

The use of seeds of higher physiological quality results in faster germination and seedling uniformity due to their higher velocity in the metabolic processes (Munizzi et al., 2010). According to França-Neto, Krzyzanowski, and Henning (2011), vigorous seeds ensure the establishment of a suitable plant stand.

\subsection{Germination of Maize Lines}

It was considered germinated de seedlings that presented protrusion bigger than $3 \mathrm{~mm}$. There was no significant difference between all maize lines at $25{ }^{\circ} \mathrm{C}$. At the temperature of $15{ }^{\circ} \mathrm{C}$, the $\mathrm{L} 30$ line had the highest germination percentage, followed by the L64, L91, and L63 lines. At temperatures above $30{ }^{\circ} \mathrm{C}$, line L91 showed to be the least sensitive with temperature variation (Table 2).

Table 2. Percentage of germination of four maize lines at five germination temperatures

\begin{tabular}{lllll}
\hline \multirow{2}{*}{ Temperature $\left({ }^{\circ} \mathbf{C}\right)$} & \multicolumn{4}{c}{ Line } \\
\cline { 2 - 5 } & L30 & L64 & L63 & L91 \\
\hline 15 & $73 \mathrm{aC}$ & $68 \mathrm{bC}$ & $27 \mathrm{cD}$ & $29 \mathrm{cD}$ \\
20 & $79 \mathrm{aB}$ & $70 \mathrm{bC}$ & $41 \mathrm{cC}$ & $43 \mathrm{cC}$ \\
25 & $94 \mathrm{aA}$ & $94 \mathrm{aA}$ & $97 \mathrm{aA}$ & $97 \mathrm{aA}$ \\
30 & $75 \mathrm{cC}$ & $89 \mathrm{bB}$ & $96 \mathrm{aA}$ & $99 \mathrm{aA}$ \\
35 & $28 \mathrm{cD}$ & $23 \mathrm{dD}$ & $82 \mathrm{bB}$ & $93 \mathrm{aB}$ \\
$\mathrm{CV}$ & 4.38 & &
\end{tabular}

Note. Means followed by the same lowercase letter in the row, and upper case in the column, do not differ at $5 \%$ probability by the Scott Knott test.

When analyzing the temperature within the lines it can be verified that lines L63 and L91 have the same pattern, where low temperatures decrease the germination percentage (Table 2).

Fancelli and Dourado Neto (2000) stated that the temperature suitable for the germination of maize varies between 25 and $30^{\circ} \mathrm{C}$, and occurring between four and five days. Temperatures below $14{ }^{\circ} \mathrm{C}$ can cause a delay in the emergence of up to two weeks (Magalhães \& Durães, 2002) and in temperatures higher than $40^{\circ} \mathrm{C}$ or near 
$10{ }^{\circ} \mathrm{C}$ the germination may not occur (Sans \& Santana, 2005). Also, Borba et al. (1995) reported that temperatures above $35^{\circ} \mathrm{C}$ cause a significant decline in germination percentage.

\subsection{Emergence of Maize Lines}

Temperatures of 15 and $20{ }^{\circ} \mathrm{C}$ contributed to the reduction of emergence in lines L63 and L91 when compared to L30 and L64. At the temperature of $25^{\circ} \mathrm{C}$, a higher emergence percentage was observed. Above the temperature of $30{ }^{\circ} \mathrm{C}$, seed emergence reduction was observed in all lines (Table 3 ).

Table 3. Emergence percentage of four maize lines at five germination temperatures

\begin{tabular}{lllll}
\hline \multirow{2}{*}{ Temperature $\left({ }^{\circ} \mathbf{C}\right)$} & \multicolumn{4}{c}{ Line } \\
\cline { 2 - 5 } & L30 & L64 & L63 & L91 \\
\hline 15 & $40 \mathrm{aD}$ & $36 \mathrm{aC}$ & $6 \mathrm{bE}$ & $12 \mathrm{bE}$ \\
20 & $54 \mathrm{aC}$ & $58 \mathrm{aB}$ & $24 \mathrm{cD}$ & $28 \mathrm{bD}$ \\
25 & $96 \mathrm{aA}$ & $94 \mathrm{aA}$ & $92 \mathrm{aA}$ & $96 \mathrm{aA}$ \\
30 & $68 \mathrm{bB}$ & $64 \mathrm{cB}$ & $72 \mathrm{bB}$ & $78 \mathrm{aB}$ \\
35 & $10 \mathrm{cE}$ & $12 \mathrm{cD}$ & $58 \mathrm{aC}$ & $48 \mathrm{bC}$ \\
$\mathrm{CV}$ & 9.27 & & \\
\hline
\end{tabular}

Note. Means followed by the same lowercase letter in the row, and upper case in the column, do not differ at $5 \%$ probability by the Scott Knott test.

The low soil temperature during sowing contributes to the delay of germination, the transport of seed reserves, and consequently the speed of emergence (Magalhães \& Durães, 2006). However, maize presents genetic variability for germination at low temperatures, so it is necessary to select good genotypes for this trait and to use them under these stresses conditions, guaranteeing greater crop success (Cruz et al., 2007).

\subsection{Emergence Speed of Maize Lines}

Temperatures of 15 and $20^{\circ} \mathrm{C}$ resulted in a low rate of emergence for lines L30, L64 and L91, followed by L63 (Table 4). The temperatures of 25 and $30^{\circ} \mathrm{C}$ presented higher values, and consequently a higher physiological potential. For these temperatures, lines L30 and L64 obtained superior results when compared to L63 and L91. With the temperature of $35^{\circ} \mathrm{C}$, the emergency speed decreased for the lines L30, L91, and L64, respectively. However, L63 presented better behavior in relation to the others.

Table 4. Emergence speed of four maize lines at five germination temperatures

\begin{tabular}{lllll}
\hline \multirow{2}{*}{ Temperature $\left({ }^{\circ} \mathbf{C}\right)$} & \multicolumn{4}{c}{ Line } \\
\cline { 2 - 5 } & L30 & L64 & L63 & L91 \\
\hline 15 & $8 \mathrm{aC}$ & $7 \mathrm{aC}$ & $9 \mathrm{bB}$ & $8 \mathrm{aC}$ \\
20 & $7 \mathrm{aB}$ & $6 \mathrm{aB}$ & $8 \mathrm{bB}$ & $7 \mathrm{aC}$ \\
25 & $4 \mathrm{aA}$ & $4 \mathrm{aA}$ & $5 \mathrm{bA}$ & $5 \mathrm{bA}$ \\
30 & $3 \mathrm{aA}$ & $3 \mathrm{aA}$ & $4 \mathrm{bA}$ & $4 \mathrm{bA}$ \\
35 & $6 \mathrm{bB}$ & $7 \mathrm{cC}$ & $5 \mathrm{aA}$ & $6 \mathrm{bB}$ \\
$\mathrm{CV}$ & 1.34 & &
\end{tabular}

Note. Means followed by the same lowercase letter in the row, and upper case in the column, do not differ at $5 \%$ probability by the Scott Knott test.

According to Cruz et al. (2007), low soil temperatures delay germination, decrease reserve mobilization, and consequently the emergence velocity. Temperatures above the optimal value for germination, also lead to the delay of the process, causing the seeds to become less vigorous (Delouche, 2004).

For the temperatures of 15 and $20^{\circ} \mathrm{C}$, it was observed a better performance from the lines L30 and L64. Lines L63 and L91, on the other hand, presented better results for the evaluated traits at temperatures of 30 and $35{ }^{\circ} \mathrm{C}$. All lines showed good performance at $25^{\circ} \mathrm{C}$. 
In this way, it is perceived the enormous importance of knowing the genetic materials that will be used for planting, and whether it is fit or not for local conditions. Specific lineages for certain temperatures when used correctly present a higher germination rate, physiological potential, and consequently normal seedlings, which will guarantee an ideal stand in the field, which will lead to higher productivity and ultimately higher yield.

Castro et al. (1997) and Leite, Brighenti, and Castro (2005) reported that during the early stages of plant development, low temperatures can cause deformation of the leaves and the apex of the plant, causing some anomalies such as stem branching. In the case of high temperatures, the development of the plant is negatively affected, due to low water availability. In addition, it may alter the constitution of cell membranes, affecting the metabolic processes, especially photosynthesis and cellular respiration (Taiz \& Zeiger, 2004).

The evaluation of temperature-controlled substrate germination was a very effective technique for the identification of susceptible and tolerant lines since the stress conditions presented in the test are the ones that most resemble the field, unlike those performed in laboratories with conditions controlled and standardized.

Genetic materials with different characteristics must be subjected to different stress conditions in order to indicate the best one for each condition. In addition, the selection of new genetic materials adapted to different environmental conditions, especially the temperature, is extremely important for a good yield.

\section{Conclusions}

Lines L63 and L91 are more susceptible to low germination temperatures and Lines L30 and L64 do not tolerate high temperatures.

Also, the evaluation of temperature-controlled substrate germination proved to be a promising technique to identify tolerant and susceptible lines for germination in both high and low temperatures.

\section{Acknowledgements}

This study was financed in part by the Coordenação de Aperfeiçoamento de Pessoal de Nível Superior-Brazil (CAPES)-Finance Code 001.

\section{References}

Borba, C. S., Andrade, R. V., Azevedo, J. T., Andreoli, C., \& Purcino, A. A. C. (1995). Germinação de Sementes de Diversos Genótipos de Milho Tropical (Zea mays L.) em Diferentes Temperaturas. Revista Brasileira de Sementes, 16(2), 141-144. https://doi.org/10.17801/0101-3122/rbs.v17n2p141-144

Carvalho, N. M., \& Nakagawa, J. (2000). Sementes: Ciência, Tecnologia e Produção (4th ed., p. 588). Jaboticabal-SP: UNESP. https://doi.org/10.17801/0101-3122/rbs.v22n1p185-192

Castro, C., Castiglloni, V. B. R., Balla, A., Leite, R. M. V. B., Karam, D., Mello, H. C., Guedes, L. C. A., \& Farias, J. R. B. (1997). A cultura do girassol (Embrapa CNPSo-Circular Técnica, n. 13, p. 36). Londrina, EMBRAPA-CNPSo.

Costa, J. G., \& Campos, I. S. (1997). Recomendações básicas para a produção de sementes de milho no nível da pequena propriedade rural (Instrução Técnica, n. 4). Acre: EMBRAPA.

Cruz, H. L., Ferrari, C. S., Meneghello, G. E., Konflanz, V., Zimmer, P. D., Vinholes, O. S., \& Castro, M. A. S. (2007). Avaliação de Genótipos de Milho para Semeadura Precoce sob Influência de Baixa Temperatura. Revista Brasileira de Sementes, 20(1), 52-60. https://doi.org/10.1590/S0101-31222007000100008

Delouche, J. C. O. (2004). Problema nem sempre é a Qualidade das Sementes. Revista Seed News, Pelotas.

Durães, F. M., Chamma, H. M. C. P., Costa, J. D., Magalhães, D. C., \& Borba, C. S. (1993). Índices de vigor de sementes de milho (Zea mays L.) associados com emergência no campo e rendimento de grãos. Revista Brasileira de Fisiologia Vegetal, 5(1), 90.

Edmond, J. B., \& Drapala, W. J. (1958). The effects of temperature, sand and soil, and acetone on germination of okra seed. Proceedings of the American Society Horticutural Science, 71, 428-434.

Fancelli, A. L., \& Dourado Neto, D. (2000). Ecofisiologia e fenologia. Produção de milho (pp. 21-54). Guaíba: Agropecuária.

Ferreira, D. (2014). Sisvar: A Guide for its Bootstrap procedures in multiple comparisons. Ciência agrotecnologia, 38(2), 109-112. https://doi.org/10.1590/S1413-70542014000200001

Franca-Neto, J. B., Krzyzanowski, F. C., \& Henning, A. A. (2011). Sementes de soja de alta qualidade: A base para altas produtividade (pp. 1-4). Congreso de la Soja del Mercosur 5, Foro de la Soja Asia 5, Rosário. Anais... Rosario, Brazil. 
Leite, R. M. V. B. C., Brighenti, A. M., \& Castro, C. (2005). Girassol no Brasil. Londrina, PR: Embrapa Soja.

Lopes, J. C., Capucho, M. T., Martins Filho, S., \& Repossi, P. A. (2005). Influência de temperatura, substrato e luz na germinação de sementes de bertalha. Revista Brasileira de Sementes, 27(2), 18-24. https://doi.org/ 10.1590/S0101-31222005000200021

Magalhães, P. C., \& Durães, F. O. M. (2002). Cultivo do milho: germinação e emergência (p. 9). Embrapa Milho e Sorgo.

Magalhaes, P. C., \& Durães, F. O. M. (2006). Fisiologia da produção de milho (p. 72). Embrapa Milho e Sorgo.

MAPA (Ministério da Agricultura, Pecuária e Abastecimento). (2009). Regras para análise de sementes (p. 395). Brasília, Brazil.

Munizzi, A., Braccini, A. L., Rangel, M. A. S., Scapim, C. A., \& Albrecht, L. P. (2010). Qualidade de sementes de quatro cultivares de soja, colhidas em dois locais no estado de Mato Grosso do Sul. Revista Brasileira de Sementes, 32(1), 176-185. https://doi.org/10.1590/S0101-31222010000100020

Nerson, H. (2007). Seed Production and Germinability of Cucurbit Crops. Seed Science Biotechnology, 1(1), $1-10$.

Sans, L. M. A., \& Santana, D. P. (2005). Cultivo do Milho-Clima e solo. Sete Lagoas: EMBRAPA Milho e Sorgo.

Silva-Neta, I. C., Pinho, E. V., Veiga, A. D., Pìnho, R. G., Guimarães, R. M., Caixeta, F., \& Marques, T. L. (2015). Expression of genes related to tolerance to low temperature for maize seed germination. Genetics and Molecular Research, 14(1), 2674-2690. https://doi.org/10.4238/2015.March.30.28

Taiz, L., \& Zeiger, E. (2006). Plant Physiology (4th ed.). Sinauer Associates, Sunderland, MA.

\section{Copyrights}

Copyright for this article is retained by the author(s), with first publication rights granted to the journal.

This is an open-access article distributed under the terms and conditions of the Creative Commons Attribution license (http://creativecommons.org/licenses/by/4.0/). 